\title{
Arts and humanities research, redefining public benefit, and research prioritization in Ireland
}

\author{
Andrew Gibson \\ Technological University Dubin, andrew.gibson@tudublin.ie \\ Ellen Hazelkorn \\ Technological University Dublin, ellen.hazelkorn@tudublin.ie
}

Follow this and additional works at: https://arrow.tudublin.ie/hepruart

Part of the Education Policy Commons, and the Higher Education Commons

\section{Recommended Citation}

Andrew G. Gibson, Ellen Hazelkorn, Arts and humanities research, redefining public benefit, and research prioritization in Ireland, Research Evaluation, Volume 26, Issue 3, July 2017, Pages 199-210, DOI:

10.1093/reseval/rvx012

This Article is brought to you for free and open access by the Higher Education Policy Research Unit at ARROW@TU Dublin. It has been accepted for inclusion in Articles by an authorized administrator of ARROW@TU Dublin. For more information, please contact arrow.admin@tudublin.ie, aisling.coyne@tudublin.ie, gerard.connolly@tudublin.ie.

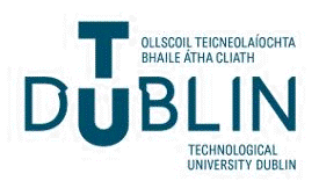




\title{
Arts and humanities research, redefining public benefit, and research prioritization in Ireland
}

\author{
Andrew G. Gibson ${ }^{1,2,3, *}$ and Ellen Hazelkorn ${ }^{2,3}$ \\ ${ }^{1}$ Culture, Academic Values and Education (CAVE) Research Centre, Trinity College Dublin, Dublin, Ireland, \\ ${ }^{2}$ Higher Education Policy Research Centre (HEPRU), Dublin Institute of Technology, Dublin, Ireland and ${ }^{3}$ Centre \\ for Global Higher Education (CGHE), University College London, London, UK \\ *Corresponding author. Email: andrew.gibson@dit.ie.
}

\begin{abstract}
This article looks at the effects of a national policy of research prioritization in the years following Ireland's economic crisis. A national research prioritization exercise initiated by policymakers redefined the purpose of higher education research, and designed policies in line with this approach. Placing research for enterprise to the fore, it emphasized the economic value that subjects could return on state investments. This article examines the post-crisis policy of prioritization, its relationship with and effects on arts and humanities research, and how the notion of the benefit of research can be broadened while still addressing economic needs. It draws on 22 comprehensive semi-structured interviews with key stakeholders in Ireland's academic, policy, and civil society communities, and is part of a wider study on the contribution of higher education institution-based arts and humanities research to society and the economy.
\end{abstract}

\section{Introduction}

The global financial crisis impacted countries around the world, but in Europe, few were as profoundly affected as Ireland. Up until that point, Ireland had been the poster-child for liberal and outward-looking economic policies, which resulted in its success being touted as the rise of the 'Celtic Tiger'. The crisis brought policymakers and citizens alike back to reality with a crash, and policymaking was influenced across the board by the aftershocks from this hardest of landings. This article looks at the government's policy of research prioritization, specifically with regard to the arts and humanities, which have traditionally been considered one of Irish higher education's core strengths. It begins with an overview of higher education in Ireland and the development of the research base, and Ireland's economic woes of 2008 onwards. It then proceeds to a discussion of research evaluation, and Ireland's research prioritization, with a discussion of the pros and cons of the approach taken, and how the public benefit is conceived of in Ireland. It then considers some alternative sources of evidence (at the individual, institutional, and national levels) that demonstrate research strengths in Irish arts and humanities research, which were overlooked by policymakers in the process of research prioritization. The article concludes with some suggestions for policymakers and arts and humanities researchers.

\section{Higher education in Ireland}

Though higher education in Ireland does not date back as far as the oldest universities in Europe-notwithstanding a 'paper university' founded in Dublin by papal bull by Clement V in 1312 (Gwynn, 1938)-its diversity testifies to the social and cultural changes throughout the island's history. This is seen in Trinity College Dublin's foundation in 1592 as an institution of the ruling Protestant colonial class, through to the Pontifical University in Maynooth founded in 1795 for the education of Irish seminarians. It includes Cardinal Newman's Catholic University of Ireland for the majority, lay Catholics, as well as the Queen's University of Ireland colleges in Belfast, Cork, and Galway in the 19th century. Following political independence from the UK in 1922, the new Irish state ${ }^{1}$ was slow to prioritize higher education. Emerging from colonial rule, the political nationalism of the ruling parties promoted a combination of cultural-religious (i.e. Catholic) identity and economic self-sufficiency heavily reliant on protectionist import-substitution industrialization and high tariff barriers (Kirby \& Murphy 2011: 17).

Neutrality in World War II (referred to in Ireland as the Emergency') followed by post-war isolation meant that Ireland failed to participate in the reconstruction in Europe that saw large investment for development, nor did it experience the levels of 
economic growth seen in Britain and continental economies. What policy existed instead of this amounted to a politics of cultural defence, which left both the economy and cultural life in a state of enervation, such that 'Irish intellectual life [...] hit some kind of nadir' (Garvin 2005: vii, 69). By the late 1940s, it was clear that economic protectionism was not working, and a new strategy beginning 1959 marked a volte-face, and has tied Ireland's economic fortunes ever since, for better and worse, to world markets and foreign direct investment (FDI). The continuing legacy of FDI is seen in Ireland's export-oriented and services-based knowledge-intensive economy, with 'medical and pharmaceutical products' and 'organic chemicals' comprising $46 \%$ of Ireland's total exported goods as of January 2016 (CSO 2016: 30), and computer services making up 47\% of total exported services in 2013 (CSO 2015).

Developments in higher education during the second half of the 20th century matched these economic changes. The elite features of the university system that only served a small element of Irish society began to be balanced out beginning in the late 1960s with the establishment of the Regional Technical College (RTC) sector. The newly created binary system met the government-defined need to expand and diversify higher education "traditionally dominated by "elite" universities and meet social demand increasingly through nonuniversity institutions' (Walsh 2014: 20). Two other higher education institutions (HEIs), established in subsequent decades as National Institutes of Higher Education (NIHE), sat between the RTCs and the universities. Influenced by the Robbins Report in the UK, they were founded in Limerick and Dublin, to provide predegree technical courses, along with the prestige of degree courses in the arts and humanities (Walsh 2009: 294-297; 2014: 22).

All these new HEIs (14 RTCs and 2 NIHEs) were intended to respond to economic and labour market demands, as well as focusing on their regions. The end of the 20th century saw considerable developments, with the introduction of free tuition for Irish undergraduate students in 1996, the Universities Act (1997) referred to as 'the most significant piece of university legislation since the state was founded' (Coolahan 2008: 275), and the redesignation of RTCs as Institutes of Technology (IoTs) in 1998.

There was recognition by policymakers of the strategic importance of education for human capital informing these developments. At this stage, higher education that produced graduates was well-integrated into the economic and social fabric of the country, but HEI-based research lagged seriously behind. Coupled with the first and subsequent reports of the Expert Group on Future Skills Needs (EGFSN 1998), various reports firmly tied Ireland's future to strategic investment in research, science, and technology as essential to develop 'a vision of Ireland as a knowledge-based society' (ICSTI 1999: 2).

\subsection{Development of a research base}

Initial impetus for the changes described above came from the stark realization that the previous nationalist-isolationist policies had failed (Chambers 2014: 120-47). While the 'big bang' of opening Ireland up to international trade came with the First Programme for Economic Expansion (1958-63), it was membership of the European Economic Community in 1973 (later the EU), and close association with the OECD, that have been the dominant influences on domestic policy ever since. Human capital development and research were seen as central to the knowledge-economy paradigm (OECD 1996).

Up to the end of the 20th century, Ireland did not have a national research policy, nor did it have an investment strategy for higher education or university-based research. The small research community that existed could only access limited opportunities in Ireland, or through European Union programmes, but they had little domestic status or international reputation. Ruane and Whelan (2011: 134) identify various external conditions that drove efforts towards greater investment in research. As much greater EU funding became available, it required a national research base to access these new revenues. Another factor was that participation in the developing world economy and in world science required Ireland 'to move up the value chain', or it would no longer be able to succeed through competition for lower skilled jobs.

High-tech manufacturing that had been promoted in Ireland since the 1960s, and the international firms it had attracted, also needed growing numbers of personnel trained in research and development to maintain the Irish advantage in the international FDI landscape. A more critical perspective argued that a strong R\&D base in Ireland was required to underpin a strong knowledge-based domestic economy, less dependent upon FDI, or 'importing innovation' (Telesis Consultancy Group 1982). These opposing rationales have continued to underpin domestic policy.

The Programme for Research in Third-Level Institutions (PRTLI) (1998-2015) marked a significant turning point. It inaugurated unprecedented levels of government funding for research, with $€ 1.2$ billion invested over this period. Managed by the Higher Education Authority (HEA, Ireland's intermediary organization), PRTLI established the first competitive framework for research to grow capacity and capability within HEIs. As well as this, two new research councils were established in 2000, under the auspices of the HEA, the Irish Research Council for Science, Engineering and Technology and the Irish Research Council for Humanities and Social Sciences (IRCHSS), initially with an annual budget of around $€ 24$ million and $€ 10$ million, respectively (Dagg 2006). These were followed by Science Foundation Ireland (SFI) in 2001, which was 'to invest in basic research in economically strategic priority areas' (Coolahan 2008: 277). SFI has consistently been responsible for the largest amount of direct government higher education research and development (HERD) funding ( $€ 135$ million, or $35 \%$ in 2012 ), with a focus on science, technology, engineering, and maths (STEM) (DJEI 2015a: 18).

The Strategy for Science, Technology and Innovation 2006-2013 (SSTI) continued the Irish government's attention on the role of research, and was the first broad strategy to address the full spectrum of research, 'basic' and targeted, encompassing STEM and arts, humanities, and social sciences (AHSS) subjects. By this time, Ireland had long since embraced the knowledge economy and the notion of 'Ireland, Inc.' (see Hazelkorn, Gibson, and Harkin 2015). Building Ireland's Knowledge Economy (Forfás 2004), an inter-departmental committee report, had firmly set Ireland on the road to carving out a position for itself in world science. SSTI followed this, and had the intention of putting Ireland 'on the map' in terms of global science as a part of the National Development Plan, no longer to have research merely content to serve national scale objectives.

The SSTI report set out key strengths in Ireland, such as the ability to attract high-tech FDI to Ireland, and a commitment to the tenets of the knowledge economy. It also drew attention to the '[h]istoric absence of a fully developed national strategy for STI, and integration of sectoral and socio-economic research within that framework' (Forfás 2006: 89-90). SSTI described a need to '[b]uild on recent NDP investments to deliver a sustainable, world class research system across the spectrum of humanities, physical and social sciences' (Forfás, 2006: 14). It noted further on that 
there are compelling social and economic reasons to further develop our capabilities in the Humanities and Social Sciences. These include: better understanding of the very rapid changes taking place in the Irish economy and society; the importance of that knowledge and understanding in better informing public policy making; and developing creative and analytical skills in the context of a global economy which is becoming increasingly dominated by knowledge based services. (Forfás 2006: 30-1)

Not long after this, however, international events intervened to change the direction of Irish research policy.

\subsection{Economic crisis and response}

The global financial crisis of 2008 and ensuing collapse of the Irish economy (see Kirby 2010) interrupted Ireland's long run of growth and also had the inevitable effect of changing the landscape for publicly funded research. Reports produced in the wake of the crisis reiterated the government's commitment to the ideal of a knowledge or knowledge-based economy, but they began questioning the type of research being undertaken and its overall impact, benefit, and relevance, and the importance given to doctoral training.

Reforming and restructuring higher education, focusing on the importance of the overall capacity of the 'system', through greater collaboration and critical mass-as well as mergers and rationalization-became a central feature of the period (Harkin and Hazelkorn 2014). Economic relevance trumped excellence in research, and science and technology came to be strongly aligned to industrial sectors that were internationally competitive. Previously PRTLI and SSTI represented a temporary truce of sorts between those who argued the virtue of broad-based research and postgraduate training versus those proposing a limited number of (semi)autonomous, commercially focused research institutes (DES 2011). Following the economic crisis, the funding picture began to change as the government pursued a more targeted approach. Research relevance defined principally in terms of job creation became the paramount criteria, with an emphasis on science and technology.

\section{Research and evaluation}

There has been a 'politics of large numbers' dating back at least to the 17th century (Desrosières 1998: 18), and arguably as far back as William the Conquerer's 'Domesday Book' (Creveld 1999: 145). The evaluation wave which has washed over many countries in recent decades (Dahler-Larsen 2007, 2015: 21-3) is the latest and most sophisticated example of the governmental impulse to make all activities undertaken in a country 'legible' (Scott 1998) to the powers that be. At first this governance by numbers was linked to state formation and control, with collection of taxation as central. The recent evaluation wave from the 1990s, however, has been concerned more with appropriate and efficient use of government expenditure. As such, evaluation touched all those areas where the state had influence, education being one of the first through 'PISA shock' and resulting discussion of educational reforms in the wake of international comparative studies (Filsinger 2016: 4).

With specific regard to higher education, evaluation is of increasing importance, given that higher education (through human capital development as well as research and development) is viewed as central to ensuring economic growth (Taylor 2016), for instance through knowledge exchange activities (Hughes and Kitson 2012), even though evaluation may purport to tell us more than it actually can (Donovan, 2007). Ireland is not immune from this view of knowledge exchange and higher education (Zhang, Larkin, and Lucey 2016). Evaluations can serve a number of 'societal functions', such as producing knowledge for decision-making, learning processes on an ongoing basis to discover how a system is performing, and performance control (Stockmann and Meyer 2016: 239-40). In Ireland, there is also a broader concern, which is the public requirement for accountability across the board in the wake of the economic crisis. The pressure this protracted crisis has put on the public purse connects with a political requirement to link publicly funded research with some kind of economic return (Hazelkorn et al. 2013: 72-6). In terms of higher education systems and research evaluation proper, four primary functions have been identified, namely, providing an overview of HEIs and their activities, accountability to government, to inform funding, and more broadly to understand the way in which research impacts on society (Penfield et al. 2014: 22).

All of these elements have suppositions specific to them, and as such the first stage of evidence gathering involves questions about the type of evidence to be gathered, and the appropriateness of one form (e.g. quantitative, bibliometrics, other metrics) versus another (e.g. qualitative, case studies, peer judgement). There is also the issue of what fields or subjects are better served by differing forms of data. For instance, humanities research has its own characteristic research outputs that invite specific forms of or approaches to evaluation, and is not best served by the same bibliometric measures that might work in the sciences (KNAW 2005; Huang and Chang 2008; Butler 2010; Pinto and Fernandes 2015), and a more complete picture might be adopted through other measures (Royal Irish Academy 2011; Hammarfelt 2014) or alternative ways of viewing arts and humanities research as a part of the research ecosystem (KNAW 2011: 25-6).

As noted above, there are a number of uses to which the information resulting from evaluations may be put, such as to inform performance-based research funding systems (Hicks 2012), or less narrowly to as an accountability mechanism for higher education, as a way of ensuring 'value for money' (Morgan 2014: S72). Prioritization is also one of the uses to which an assessment or an evaluation could be put. In an ideal version, prioritization would emerge from an evidence-based process, involving assessment (as evidence gathering), evaluation, and discussion, before any research priorities are defined. There is also, however, the possibility that evaluation can be used to legitimize existing policies (Stockmann and Meyer 2016: 240) or other political requirements. However valuable, wide-ranging assessments are neither cheap to implement nor to run, in terms of both economic (Geuna and Piolatto 2016) and political capital (Dahler-Larsen 2015: 33). As such, if there are more pressing concerns in a country's social-economic and political context, these may influence the rationale underlying a research evaluation or prioritization, and priorities may not result solely from an evaluation.

\subsection{National research prioritization exercise}

Ireland's National Research Prioritisation Exercise (NRPE) marked the end of what had been a strategy to build a broad base of expertise in higher education through government policies and schemes such as SSTI and PRTLI. The government-appointed steering group met between October 2010 and September 2011, and published its findings later that year. It noted that policy 'in the area of research and innovation has served us well but it is appropriate to move towards a more top-down, targeted approach at this point' (Forfás 
2012: 8). The use of language, most notably 'at this point', identified the context. More significantly, it regarded development of a research base as effectively complete, and the task was now to 'build on the strengths that have emerged from the investment that has taken place' (Forfás 2012: 8). Its focus was publicly funded research, but excluded the 'block grant" ${ }^{2}$ and enterprise-based research (such as through the State's enterprise agencies, the Industrial Development Agency, or Enterprise Ireland).

Three over-arching goals were identified, which defined research in terms of that oriented towards the Irish enterprise base, research for policy, and research for knowledge (Forfás 2012: 8-9). The latter two goals were subordinate to the first, referencing the working group's interpretation of the terms of reference continued to note that it had 'deliberately focused its attention on publicly-funded research that is oriented to the Irish enterprise base (i.e. natural resource sectors, manufacturing sectors and market services sectors of the economy)' (Forfás 2012: 9, see also 25).

Four criteria were used to identify potential priority areas: association with large global markets in which Irish-based enterprise does or can realistically compete; public investment in $R \& D$ is necessary and can complement existing private sector research; Ireland has objectively measured strengths; and the field represents a national or global challenge to which Ireland should respond (Forfás 2012: 87). Specific working groups were established, with defined remits: health, well-being, and ageing; natural resources and sustainable environment; technology, social media, creative and cultural enterprise; and innovative processes for enterprise (advanced manufacturing and business services).

\subsection{Prioritization without evaluation}

The NRPE was narrowly conceived from the outset. The events which resulted in the Irish economic collapse meant that the country saw a decline of real gross domestic product (GDP) by $10 \%$ over 2008 and 2009 (Whelan 2014: 429), and this framed the policy response across government departments, including in research policy and its priorities. With unemployment running at $14.6 \%$ in 2011 (CSO n.d.), it was not surprising that the overarching objective of the exercise was to identify priorities which best matched a view of international competitiveness. In choosing that criterion, rather than for example disciplinary excellence or societal challenges, it was inevitable that some fields of research would effectively be excluded. One policymaker explained the rationale underlying this:

there are probably 4-6 things that Ireland needs to [...] to focus on. And they are: the life sciences, ICT, medical devices, food, and so on; we all know what they are. And we need to make sure we stay best at those. And then, we also need to look at what is coming down the pipe that would be natural for us to get into. And we need to establish ourselves there. (P3) ${ }^{3}$

As such, the guiding notion of enterprise-focused research led the entire NRPE process. The final outcome of the research prioritization process was that the working groups settled on 14 priority areas ${ }^{4}$. From this, six specific fields such as biomedical science, nanotechnology, advanced materials, microelectronics, photonics and software engineering were identified as the 'platforms' that would underpin the identified priorities. The NRPE steering group relied upon substantial economic data sets as well as bibliometric studies of journals indexed in Thomson Reuters' Web of Science database conducted by Thomson Reuters' consulting arm (EVIDENCE 2009, 2010).

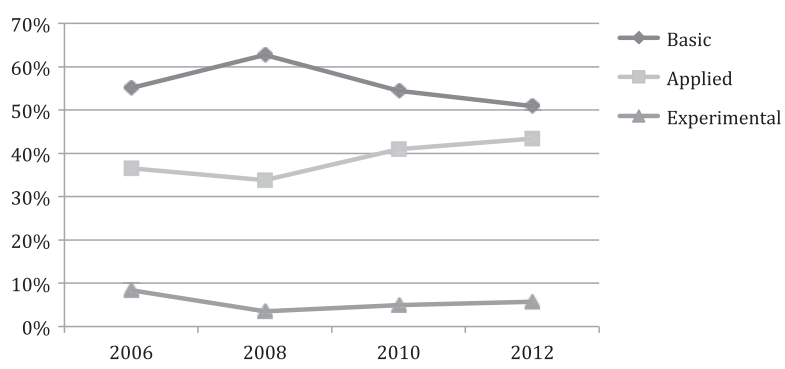

Figure 1. Proportion of Higher Education R\&D funding by type ${ }^{5}$ of research, 2006-2012.

Source: Compiled from Forfás and Department of Jobs, Enterprise and Innovation data.

It was suggested that the 14 areas were 'broad enough to involve the full spectrum of research' involving 'researchers across all disciplines and sciences: physical and life sciences, technology, services, engineering, arts, humanities and social sciences' (Forfás 2011: 9). The specificity of the chosen priority industrial sectors and enabling technology platforms, however, and the lack of any realistic pathway by which AHSS researchers could participate, suggests this was lip-service. Indeed, an independent review of NRPE noted areas excluded by prioritization, and what this meant for higher education research, and 'the absence of an agreed national strategy':

...other research funders have had no option other than to implement individual, parallel strategies, which is suboptimal from an efficiency perspective and has resulted in the emergence of lacunae in the system. For many research areas, including most of the Humanities and Social Sciences, and basic and applied STEM outside the 14 priority areas, the only national funding schemes available are those administered by the Irish Research Council. (DJEI 2015b: 13)

Arguably there is nothing wrong with stating national objectives (i.e. research for enterprise) and working backwards from that. Indeed, emphasis on research excellence can lead to fragmentation, depending upon the criteria for excellence and critical mass in that area. On the other hand, favouring excellence can be supportive of scientific serendipity, which is vital.

The choice of the 14 areas has had wider implications for higher education beyond this however. While the Universities Act set out the benefits of public research (see Section 3.1 below), NRPE sought to reorient the future of Irish research saying the 14 priority areas 'should become the focus of future research investment that is oriented towards the Irish enterprise base' (Forfás 2011: 25) and that the majority of funding should be allocated to these areas and their platforms. To strengthen its case, it argued enterprise-focused research 'has always accounted for, and should continue to account for, the largest proportion of Government investment in R\&D' (Forfás 2011: 9) and that 'most public investment in research in Ireland is driven by an economic motive' (Forfás 2011: 21). Yet, as Figure 1 below illustrates, basic research has tended to be the largest proportion, contradicting NRPE's view of the role played by Irish research. NRPE's intent, having identified priorities areas and 'research for enterprise', both of which broadly correspond with applied research, was to reverse this historical trend.

There is a bigger picture underlying these changes in the direction. At one level, there was a shift in authority for research from the Department of Education and Skills to the Department of Jobs, 
Enterprise and Innovation, which was intended to ensure greater coherence in research and research funding. The change has signified a more fundamental restructuring of research however. Following the economic crisis, the role and budget for SFI was expanded, the NRPE was adopted as the de facto national research strategy, and the humanities and social sciences research council, IRCHSS, was merged with its STEM equivalent to form the Irish Research Council. This coincided with the marginalization of the HEA and its parent Department of Education and Skills in research policy-and foreshadow a more fundamental shift away from research having its primary home within higher education, to having its role in external-facing or independent industry-oriented research centres (Arnold et al. 2012).

\section{The public benefit of research and prioritization}

As the research base for Irish research expanded during the early years of this century, arts and humanities research was central. Between 2000 and 2006 research funding for the humanities more than doubled on the back of PRTLI funding (Forfás 2008). In the period following the financial crisis, the policy focus was concentrated on economically relevant research, with the implication that STEM research was front and centre in policy discourse. What is interesting about this for the arts and humanities, however, is how this policy focus appears not to have had an impact on research funding. Although the economic crisis meant that overall HERD funding declined from $€ 750$ million in 2008 to $€ 621$ million in 2012 (the most recent available data), as a percentage of total HERD the humanities have remained relatively stable, at $8 \%$ of HERD funding (see Supplementary Figure S1). The humanities' $€ 50$ million (8\% of HERD) in 2012 was well above 2002's figure of $€ 33$ million, and only slightly lower than 2008's high of $€ 56$ million, and while there was a $€ 24$ million decline from 2008 to 2010 , this was back up again in 2012 (DJEI 2015a: 21).

Because the NRPE deals with competitive funding, which is not a significant element of funding available to arts and humanities researchers, there is no decline evident in the funding available to those arts and humanities researchers as a result of the NRPE. The 'crisis of humanities funding' may be a crisis that feeds off the perception of the situation. ${ }^{6}$ It is a matter of 'where the stress falls' in Irish research policy, and a problem of perception rather than reality, namely, the perception of unremitting decline, which the HERD data does not bear out. There is another issue of perception, however, in that while the NRPE ostensibly does not exclude the arts and humanities, the way in which the priorities have been framed raises some scepticism as to the intention behind such claims, and is a missed opportunity to frame a more capacious understanding of the public benefit of research.

A broader understanding of the arts and humanities is possible, one that includes their established role in contributing to civil society, as well as a broader contribution that can include tourism, for example, which is underpinned by the arts and humanities in its many forms. One of our interviewees from academia made just this point:

Tourism is supposed to be our biggest industry; what do tourists want in terms of cultural arts and humanities experience. That's why a lot of people are coming here; they're not going to visit our science parks or incubation centres; they're coming here for an experience $[\ldots]$ Why are they actually coming to Ireland? It's not because of the weather. (A2)

Pushing towards a utility-driven model that is structurally biased against the arts and humanities precludes such a broader understanding of the role played by the arts and humanities.

The statistics referred to above of course do not fully capture the place held by the arts and humanities in Ireland. Indeed, in the modern era, Ireland and Irishness was a historical, linguistic, and cultural reality long before it became a political one. Similarly, Irish higher education as an elite structure long had a classical bent, and did not focus on economic application or any other sense of what would later be considered 'applied knowledge' until the development of the binary system. This did not wane as higher education was foregrounded as of central importance to FDI and the knowledge economy. Indeed, the Universities Act, 1997 enshrined the broader public benefit of higher education unambiguously when describing the 'objects' of the university ${ }^{7}$ in Irish society, some of which are as follows:

12. The objectives of a university shall include:

a. to advance knowledge through teaching, scholarly research and scientific investigation,

b. to promote learning in its student body and in society generally,

c. to promote the cultural and social life of society, while fostering and respecting the diversity of the university's traditions,

d. to foster a capacity for independent critical thinking amongst its students,

e. to promote the official languages of the State, with special regard to the preservation, promotion and use of the Irish language and the preservation and promotion of the distinctive cultures of Ireland,

f. to support and contribute to the realisation of national economic and social development. (Oireachtas Éireann 1997)

The 'public good' function of higher education is implied, with the aim of the university being 'to do all things necessary or expedient $[\ldots]$ to further the objects and development of the university'. The arts and humanities are explicitly mentioned with items (c), (e), and (f). The economic development function of higher education is also present, but is no more or less important than the other roles that the university is obliged to fill, and there are clear tensions between this legislation and the new national priorities put forward through research prioritization.

\subsection{Irish arts and humanities research after the crisis}

The UK for some time has had a 'burgeoning "impact" rhetoric' (Belfiore and Upchurch 2013: 6) which in due course was followed by policy and instruments such as the Research Excellence Framework; the Netherlands has its own equivalent in the concept of research 'valorization' (Benneworth and Jongbloed 2009; Benneworth 2015). The impact discourse has increased interest and research in this area (Donovan 2011; Collini 2012: 168-77; Watermeyer 2012a; 2012b, 2014; Belfiore 2014; Oancea 2014). Ireland has not been untouched by such talk of impact (INDECON 2011; Hazelkorn 2014; Zhang, Larkin, and Lucey 2014, 2015), but policy has not followed the more formalized route favoured elsewhere. This puts the arts and humanities especially in a curious position because they are almost exclusively reliant on the public purse for their funding, and yet calls to justify the spending of this 
money-no matter how apparently 'reasonable'-appear to be a departure from how arts and humanities research has existed in Irish higher education. Accusations of side-lining of the humanities occurs in other countries (Ferrini 2014: 44), and could be an artefact of funding and research policies (Mittelstrass, 2015). Asserting the public benefit of the humanities, or relying on long-held historical justifications are no longer sufficient, however, and thus there is a need to engage with existing processes (Lund 2015: 107).

Whispers of change to a more formal research assessment process have been around for some time. A state policymaker remarked on this point that

there hasn't probably been the pressure on the humanities and social sciences community in the past to explain themselves to or justify themselves. Or there's probably been either a reticence or a resistance to actually explaining, because you do get this defensive view that this is an end in itself, this has an intrinsic value in its own right. (P7)

Though in the USA the 'culture wars' had raged since the early 1990s, implicitly forcing academics to make arguments for their work (Newfield 2011: 54-6), Ireland has not heretofore experienced the same degree of scrutiny. If researchers were forced by external forces and circumstances to consider their activities (through assessment or evaluation), there is a danger that this urgency might endanger a true evaluation of the activities being carried out. This has implications for the timescales involved, as the economic and financial crises in Ireland introduced urgency into the discussion of the importance of the arts and humanities, and how we respond to this question.

Even in crude economic terms, one policymaker (P3) noted in our interviews that 'if you're using a tool in the short-term to measure a long-term investment, then of course the tool is wrong, and you'll get the wrong outcome'. Another, civil society interviewee from a national academic organization presented a similar view from the opposite timescale:

There is no one single-measure that is the gold standard. Then again, there is the case where people do work that is good but isn't recognized at the time that it's done. It could be a hundred years later in some cases that people appreciate how important it was. And that affects the sciences just as much as the humanities. (C6)

In the period of the SSTI, before the economic crisis, there had been some discussion of the role of the humanities. The Royal Irish Academy published a policy report, Advancing the Humanities and Social Sciences in Ireland (Royal Irish Academy 2007), in response to which the then Minister for Education and Science asked that the HEA and IRCHSS implement one of the key recommendations, which was to reflect on the contribution of the humanities and social sciences to the development of Ireland. As a result, the Foresight Exercise for the Arts, Humanities, and Social Sciences (FAHSS) was initiated.

In submissions to FAHSS, stakeholders from industry and business identified the importance of the arts and humanities for tourism, digital media, and even international financial services, but overall for 'generic skills' (Forfás 2008). A submission from the Irish Business and Employers Confederation (IBEC) lamented the fact that 'knowledge transfer in the AHSS tends to be neglected by current funding policies' (IBEC 2008). This, and other submissions, suggested that the arts and humanities could be more closely integrated in discussions of research relevance. Though discussions had started, both the tone and the content of the conversation changed after the crisis.

\section{Alternative perspectives on Irish arts and humanities research}

Detailed work has been done on identifying the characteristics of humanities research (Ochsner, Hug, and Daniel 2013) and establishing criteria for excellence in humanities research (Hug, Ochsner, and Daniel 2013). The application of such criteria to the Irish context are, as of yet, some way off. While it is true that there is and has been no national assessment or evaluation of the entire public research base in Ireland, there is evidence to show the relative strengths of different subject fields and areas.

For example, there are proxies, which bring out some features of the role and quality of Irish arts and humanities research. These concern the (i) individual level, (ii) institutional level, and the (iii) international level. While the NRPE looked first and foremost at absolute advantage in international terms (i.e. fields or areas where Irish research was world class), this section looks at relative strengths, to show the place of arts and humanities research relative to other fields in Irish higher education, rather than making international comparisons.

\subsection{Individual level-European Research Council peer review}

The European Research Council (ERC), introduced with the Seventh Framework Programme, has been a significant intervention by the European Union in the development of a 'research excellence drive' (Maassen and Stensaker, 2011: 763). The ERC has its own issues internally, such as the governance imbalance between bureaucrats and scientists (Enserink 2009), and research suggests that its mechanisms may err on the side of conservatism and do not reward the most innovative research (Luukkonen 2012).

Nevertheless, a survey of successful and unsuccessful ERC Starting Grant awardees found that these awards are seen to have a high reputation and prestige, as well as high-quality peer-review process (Luukkonen 2014: 36-7). Its awards and peer-review process are regarded as the gold standard in Europe, as well as in Ireland. The ERC's awards focus on individuals rather than higher levels of abstraction (research groups, departments etc.), and as such indicates research strength in a given field.

The ERC peer-review panel structure is divided into three large domains, Life Sciences, Physical sciences and engineering, and Social sciences and the humanities. These in turn are subdivided into subdomains or panels (ERC 2015: 32) One of the interesting measures of the ERC uses to present its data is the 'concentration index'8 which 'shows the research areas, as demarcated by the ERC panels, in which a certain country exhibits a relative strength' (ERC 2015: 70). Ireland's thematic concentration index across all panels is in Table 1 below.

The highest figure in terms of Ireland's 'concentration index' as defined by the ERC is in subpanel PE08, 'Products and Process Engineering'. This maps on to one of the 14 priority areas in the NRPE, area M 'Processing Technologies and Novel Materials'. The second highest concentration index is subpanel SH06, which is 'The Study of the Human Past', firmly within the humanities. The third highest figures are for LS07 'Diagnostic tools, thearapies and public 
Table 1. and ERC thematic concentration index by current host country (as of 21/08/2014)

\begin{tabular}{lccccccccc}
\hline Life sciences & \multicolumn{1}{l}{ L } & & & & & & \\
LS01 & LS02 & LS03 & LS04 & LS05 & LS06 & LS07 & LS08 & LS09 & \\
0.0 & 1.4 & 0.0 & 0.0 & 0.6 & 0.8 & 1.8 & 1.5 & 1.1 & \\
Physical sciences and engineering & & & & & \\
PE01 & PE02 & PE03 & PE04 & PE05 & PE06 & PE07 & PE08 & PE09 & PE10 \\
0.5 & 0.5 & 0.6 & 1.4 & 1.6 & 0.0 & 0.0 & 5.4 & 0.0 & 0.8 \\
Social sciences and humanities & & & & & & \\
SH01 & SH02 & SH03 & SH04 & SH05 & SH06 & & & & \\
0.9 & 0.7 & 1.8 & 0.0 & 1.4 & 2.8 & & & & \\
\hline
\end{tabular}

Source: Adapted from Table A8.08, ERC 2015: 105. Subpanels are indicated by two digits.

health', and SH03 'Environment and society'. LS07 again maps on to the NRPE priorities, areas E 'Medical Devices' and F 'Diagnostics'. Another humanities area, SH05 'Culture and cultural production', also does respectably in the research concentration index relative to the other subpanels in the Life Sciences and Physical Sciences and Engineering.

This does not demonstrate that Ireland's does better than any of the other areas in the ERC process, or that NRPE was wrong in the areas it chose (this is also reflected by the 'ERC Applicant Success Rate', in Supplementary Table S1, and the 'ERC Grantees, total number of awards-Ireland', in Supplementary Table S2). What it indicates, however, is that excellent research, as reviewed by international peer review, is also being performed in the humanities, and that the narrow frame by which the research priorities were defined were able to bypass this work. A government policy-officer (P7) emphasized the importance of this, saying 'ultimately good quality research is good quality research because it has been peer reviewed and people recognize it and acknowledge it as good quality research. And that has to be the major test of excellence'.

\subsection{Institutional level-institutional research thematic priorities}

As a large proportion of funding in the Irish research ecosystem is allocated according to the block grant, ${ }^{9}$ institutions still have a significant say in what they define as their own priorities, which may or may not coincide with those priorities as are found in NRPE. This is especially relevant for humanities research, given that as of 2012 the block grant made up $45 \%$ of total HERD funding (DJEI 2015a: 20). As such, a question is worth asking regarding individual institutions and their own priorities, and whether these differ from other strategies (i.e. those found in the NRPE). As with HEIs internationally, Ireland's institutions have been no different in adopting elements of strategic planning as a part of its planning processes (Elwood and Leyden 2000).

In the case of Ireland's institutions, while both sides of the binary divide are involved in research, universities perform the majority of research activity accounting for 91\% of total HERD in 2012 (DJEI 2015a: 6). Significant challenges still remain for increasing the involvement of IoTs in the higher education research landscape (Hazelkorn and Moynihan 2010). The historical differentiation in mission of the different sectors of universities and IoTs also plays a significant role, with universities having greater strengths in the humanities than the IoTs. This differentiation becomes apparent when looking at what Ireland's HEIs identify as their internal priorities in strategic statements and websites relating to research, and how this is different from the national-level strategy evinced in the NRPE.

Looking at the 7 universities and 14 IoTs, a distinctive pattern is apparent. First, six of the seven universities have clearly set out research priorities. These have various names: 'research themes' (Trinity College Dublin ${ }^{10}$ ), 'strategic priorities' (University College Dublin ${ }^{11}$ ), 'strategic thematic areas' (University College Cork ${ }^{12}$ ), 'thematic research priorities' (National University of Ireland, Galway ${ }^{13}$ ), 'thematic priorities' (Maynooth University ${ }^{14}$ ), and 'key research and innovation areas' (Dublin City University ${ }^{15}$ ). University of Limerick appears to have no over-arching, institutionlevel priorities, but some individual faculties have identified themes. Within these themes, generally there is a high level of subject abstraction, with between four and six broad areas (e.g. 'Health', 'Technology'), which may simply map on to those HEIs' faculties. Within these, there is scope for more specificity (though Trinity College Dublin reverses this, specifying 19 themes, which fall under six broad 'research directions').

Of the six universities specifying internal research priority areas, all specify at least one area in or involving the humanities. ${ }^{16}$ An interesting absence, however, is the arts in University College Dublin's 'strategic priorities', given that the National College for Art and Design ${ }^{17}$ became a recognized college of that university in 2011. Though they do not have as strong a presence in research as the universities, of those IoTs setting out research priorities (5 of 14), four mention the arts and humanities. One IoT without research priorities, the Dun Laoghaire Institute of Art, Design, and Technology, does carry out research in both the arts and humanities, however.

From this, it is clear that almost all the universities, and the IoTs to a lesser extent, have identified research in the arts and humanities as areas of strategic interest. Irish HEIs have identified the arts and humanities as just such strengths, ${ }^{18}$ and there is scope to integrate this institution-level commitment to arts and humanities research into a national-level strategy.

\subsection{National level_SCImago country ranking}

Rankings can be criticized for a variety of reasons, as much as for what they do purport to measure as what they do not (for a summary of these criticisms see Hazelkorn 2015: 62-90). On the broader level, they emphasize research at the expense of the higher education's other missions (Hazelkorn 2011; Amsler and Bolsmann 2012; O'Connell 2012), as well as issues relating to the openness of information used (Marginson 2009). There is a narrower genre that focuses on the technical details of weightings and specific metrics (Soh 2012, 2013), as well as often interesting discussion of specific rankings releases. ${ }^{19}$ Bibliometrics are a central element of rankings, and has its own vast literature of critique; De Bellis (2009) provides an overview of the history and theoretical debates attendant to this topic. Within this literature, there are also issues in bibliometrics with regard to the database coverage, forms of publication, and citation patterns, that are specific to research produced in the humanities (Giménez-Toledo, Tejada-Artigas, and Mañana-Rodríguez 2013; Stratilatis 2014: 185-8; Pinto and Fernandes 2015).

Despite the criticisms, however, rankings are remarkably consistent and arguably do say something about the higher education landscape (Hazelkorn and Gibson 2016). For this article's purposes, the above broader criticisms will be put into abeyance, to focus on SCImago's 'Country Rankings ${ }^{20}$. SCImago is a bibliometrics-based 
ranking, using its SCImago Journal Rank indicator, which relies on the Scopus database and Google's PageRank algorithm. ${ }^{21}$ As we wish to draw attention to the strengths of arts and humanities in the Irish research base, a measure across a period of time side-steps concerns about the 'noisiness' of year to year results (Dichev 2001; Bookstein et al. 2010).

SCImago has been used previously for discussion of national research performance in the humanities in Malaysia (Ahmad 2012) and Italy (Capaccioni and Spina 2012), but both discussed SCImago's coverage of humanities (and social sciences journals), rather than comparing humanities research relative to other fields, as is done here. SCImago has been subject to criticism regarding nomenclature, double-affiliation, and aggregation (de Mesnard 2012), but the focus here on nationally aggregated performance side-steps these issues.

The measure we have chosen is Ireland's performance in the country ranking, ordered by 'cites ${ }^{22}$, and over the period of 1996 to 2014. As a consequence, given Ireland's status as a small country, it will not feature in the very top of such a ranking. Nevertheless, this can serve our purposes in terms of performance of scientific fields relative to one another. In this regard, as with the ERC grants, one sees that the priority areas that were chosen in the NRPE were selected with some justification. Looking at each of SCImago's 26 subject areas (these can be further subdivided into subject categories), Ireland's highest performing fields are not out of sync with the priority areas: 'Immunology and Microbiology' is Ireland's highest ranking area at 23; followed by 'Nursing' at 24; 'Multidisciplinary', 'Neuroscience', 'Psychology', and 'Veterinary' at 25.

The next highest ranking is 'Arts and Humanities' research at 27 , followed by the remaining 18 fields. The biological and medical nature of these higher performing fields maps on to some of the priority areas identified by the NRPE, though the NRPE's bias towards research for enterprise favours technologies which can be manufactured and applied research. In contrast, SCImago covers whatever research has been published over the chosen period, which includes fundamental or basic research. This is a respectable position, and gives some sense of the relative strengths the Irish research base, though admittedly according to this one metric, in one ranking (see Supplementary Table S3 for full results).

\section{Irish research after prioritization}

There are normally always limitations to research funding; the aggregate level may vary from one jurisdiction to another but it is never unlimited. Thus, priority setting is fairly standard. Evaluation of research is always for something, and one such purpose can be to prioritize research. In the absence of a formal system or process of evaluation, however, such efforts at prioritization can be problematic, as fundamental conversations about the purpose of the evaluation are elided. The issue this article discusses is the extent to which the form priority-setting took in Ireland, in response to the economic crisis, effectively marginalized arts and humanities research in policy.

NRPE's terms of reference were clearly stated, and animated by an unambiguous principle of economic return on investment. It cannot be criticized for not addressing something that was outside its remit. Nevertheless, there are differences between apparent research strengths in the arts and humanities (as far as proxies can tell us) and what policy defines as research priorities that can be considerable. The independent review of the NRPE noted that the scarcity of funding for areas outside prioritization, 'even in some areas where Ireland had significant capacity prior to research prioritisation (RP), may undermine Ireland's ability to respond to emerging or unforeseen areas of opportunity in the future' (DJEI 2015b: 13). As one policymaker interviewee (P7) noted, it is important 'that higher education institutions through their block grant funding are able to support and sustain a strong research base', and so prioritization can only be one part of a wider research strategy.

There are elements of such a wide strategy evident in the Irish Government's Innovation 2020, the 5-year plan for R\&D, science and technology, launched in December 2015. It set out the government's intention to 'build on the significant progress of the past decade in developing Ireland's research and innovation system' and spoke of continued support for 'excellent research across the full continuum and across all disciplines' (DJEI 2015c: 8). It also affirmed a commitment to Irish Research Council (IRC) funding, and the importance of human capital and the research pipeline. It also clearly reiterated an intention to 'continue to focus the majority of competitive funding on the 14 priority areas' (DJEI 2015c: 10), setting the date for a new round of research prioritization starting in 2017, in which a 'market-led horizon-scanning exercise will be undertaken in order to identify strategic areas of commercial opportunity' (DJEI 2015c: 26).

The wider strategic view of research across all disciplines is more clearly set out in the new iteration of the Strategy for Science, Technology and Innovation (SSTI2). A consultation paper for SSTI2 points to the need to supplement the NRPE and its narrow focus on (economic) relevance and impact, saying 'it is now timely to place Research Prioritisation and the focus on research relevance and impact within a broader context and to develop and articulate a vision for science policy across all disciplines' (ICSTI 2015: 2), including arts and humanities research. This has provided an ideal opportunity for the arts and humanities to reframe their own discussion beyond the usual criticism of staffing issues, funding, and so on.

At an event in the Royal Irish Academy, one speaker noted that while higher education research is 'currently viewed as a principal component of national innovation policy, the primary economic engine of advanced societies, this new mission needs to be reconciled with earlier objectives' (Royal Irish Academy 2015: 13). Indeed, the Vice-President and Director at Intel, Martin Curley, stated: the 'key to the future is understanding that we live in a society, not an economy. Too many people forget that too often. The humanities and social sciences are vital to our future' (Duncan and Rouse 2015: 13). Disciplines are not immutable, nor are the arts and humanities freed from engaging with changing notions of relevance and public benefit. In the words of one policymaker:

regardless of your discipline, your area, there's almost a duty of care, an onus upon you as a researcher, to at least, at a minimum, to ensure that the knowledge you're generating is transferred beyond your peer-group, to others. (P5)

There are some observations to be made of the possible future implications of allowing the NRPE focus of research enterprise to remain a de facto policy. First, a narrow, short-term definition of priorities can have success, but the Irish experience raises the question of what can emerge when short-termism trumps quality. One interviewee said of the NRPE and arts and humanities research that if 'it became anyway less important than the sciences and technology, it would be incredibly short-sighted' (P1). 
This leads to the second point, which is that one of the implications of short-termism is that it can undermine wider national societal objectives, capacities, and capabilities, as well as existing institutional priorities. The independent review of the NRPE also made observation of the fact that the 'scarcity of national funding for areas outside RP, even in some areas where Ireland had significant capacity prior to RP, may undermine Ireland's ability to respond to emerging or unforeseen areas of opportunity in the future'. The report followed with the observation that a reduction of the core grant to Irish HEIs, 'which occurred independently of, but concurrently with' prioritization had undermined the capacity for research in non-prioritized areas (DJEI 2015: 13).

This observation implies a third point, which is that because research capacity takes a long time to build, and new ideas can come from surprising and unexpected quarters, there needs to be space and flexibility within any plan or strategy that leaves room for felicitous and surprising developments. A submission from the OECD to SSTI2 also noted the scope for including arts and humanities in research policy, given the 'societal challenges' approach which is increasingly being adopted by major funders (such as Horizon 2020), whereby 'STEM-HSS synergies play a key role' (OECD 2015: 6). Without the core element of funding for those areas not covered by prioritization, the felicitous aspect of surprising and unexpected research can be neglected.

\section{Conclusion: arts and humanities and the future of Irish research}

Research policy has to walk a fine line between emphasizing excellent research in all its forms, as well as prioritizing certain types of research for economic goals. This article identified proven and existing strengths in arts and humanities research, but by NRPE becoming in effect the de facto national research policy, some of the previous balance in research policy has been lost. Economic prioritization can only be one part of a national research policy.

The next point is that the NRPE approached its mission with the assumption that the research base was complete, and that those fields and sectors with most productive potential should serve the Irish society and the economy. The research base also requires maintenance, however, and planning for the future of the research pipeline, as SSTI2 and Innovation 2020 both set out.

The third point we would make is that 'enterprise research' as found in the NRPE is too narrowly conceived. In the wake of the financial crisis, Ireland chose identifying industrial sectors with potential for jobs and economic growth and trade. The next step, as Ireland's recovery continues, is to look to the future, and alternative priorities that engage societal challenges, which start with a wider base. While this doesn't exclude the economic, it does problematize issues in a different way recognizing the need to embrace multi-, trans-, and inter-disciplinary approaches. One could imagine a range of such issues including rural re-development, green/clean environment, the ageing society, and so on.

A final point we would make is that the next step and opportunity for the arts and humanities research community is to participate in this new phase of Irish research. Ireland has demonstrated strengths in the arts and humanities, strengths which have legitimacy. The task for arts and humanities researchers is to leverage their legitimacy as one of the strongest elements of the Irish research ecosystem, through the clearly defined objects of what the university is for, as well as broad existing social support for higher education. They can demonstrate that priority setting can be understood more widely, and that Ireland's challenges for the future are not just economic, but social and cultural.

\section{Funding}

This work was in part supported by the Humanities in the European Research Area programme, a network funded by the European Commission and 19 research councils responsible for arts and humanities research across Europe (Grant 09-HERA-JRP-CI-FP022).

\section{Acknowledgements}

The authors would like to sincerely thank the two anonymous reviewers, whose critical reading and suggestions improved this article. The authors would further like to note that this article was partially based on research originally conducted under the HERAVALUE project, which was originally financially supported by the HERA Joint Research Programme (http://hera net.info), co-funded by AHRC, AKA, DASTI, ETF, FNR, FWF, HAZU, IRC, MHEST, NWO, RANNIS, RCN, VR and the European Community FP7 2007-2013, under the Socio-economic Sciences and Humanities programme.

\section{Notes}

1. The 32 counties of the island of Ireland were partitioned into two countries in 1922 following the signing of the Anglo-Irish Treaty in December of 1921. The 26 counties in the south of the island was called the Irish Free State, with 6 counties in Ulster becoming Northern Ireland and remaining part of the UK. In 1937 Ireland adopted a new constitution which gave the state its two present official names, Éire in Irish, and Ireland in English (Ferriter, 2010).

2. This is the annual recurrent funding given to Irish HEIs through the HEA, which covers both teaching and research. It is core funding, allocated on the basis of student numbers, but distributed as a block to give HEIs discretion in internal funding allocation. Within the HEI, this funding is allocated according to the share of time spent by salaried academic staff on research, based on academic contracts, with staff in universities having more time allocated in their contracts for research than staff in IoTs.

3. The full coding list of interviewees is available in Hazelkorn et al. (2013: 107). The interview protocol is available in the same report (157-9).

4. They are as follows: Future Networks and Communications; Data Analytics, Management, Security, and Privacy; Digital Platforms, Content, and Applications; Connected Health and Independent Living; Medical Devices; Diagnostics; Therapeutics-Synthesis, Formulation, Processing, and Drug Delivery; Food for Health; Sustainable Food Production and Processing; Marine Renewable Energy; Smart Grids and Smart Cities; Manufacturing Competitiveness; Processing Technologies and Novel Materials; Innovation in Services and Business Processes (Forfás 2011: 10-2, with longer descriptions of each area 45-78). 
5. These definitions of basic, applied, and experimental research are the standard definitions, taken from the OECD's Frascati manual.

6. As well as the drop from 2008 to 2010 detailed above, it may also feed off the composite notion of 'Arts, Humanities, and Social Sciences', as the HERD funding for the social sciences has declined from $19 \%$ in 2008 to $14 \%$ in 2012. See Supplementary Figure 1 for more detail.

7. The Regional Technical Colleges Act, 1992 (Oireachtas Éireann 1992) also refers to one of the functions of the RTCs-now IoTs-being to 'provide vocational and technical education and training for the economic, technological, scientific, commercial, industrial, social and cultural development of the State... The IoTs have a much smaller role in arts and humanities research than the universities, however, given their foundation as colleges for technical education, and not withstanding some subsequent academic drift (Clancy 2015: 292).

8. In a personal communication from the ERC, it was clarified that the concentration index was calculated as follows: $\mathrm{I}=\frac{G_{i j}}{\Sigma_{i} G_{i j}}\left[\frac{\Sigma_{i} G_{i j}}{\Sigma \Sigma_{i j} G_{i j}}\right]^{-1}$, where G: count of grants, i: country index, $\mathrm{j}$ : panel index. A table detailing Ireland's success rates and the number of grants are included in the supplementary data.

9. There has been some discussion recently regarding the extent to which composite research funding, allocated either through the block grant or the NRPE, is aligned with the priority areas, but there is no data on this.

10. https://www.tcd.ie/research/themes/.

11. http://www.ucd.ie/research/whatweresearch/strategicpriorities/.

12. http://www.ucc.ie/en/research/overview/strengths/.

13. http://www.nuigalway.ie/our-research/listings/.

14. https://www.maynoothuniversity.ie/research.

15. http://dcu.ie/research/key-research-areas.shtml.

16. Of its six higher level 'research directions', Trinity specifies two involving arts and humanities, and of its 19 'research themes', 2 are in the arts and 4 in the humanities, the highest of any Irish HEI.

17. NCAD itself specifies its own research priorities however: http://www.ncad.ie/research-and-innovation/research-prior ities-2012-2016/.

18. In 2009, University College Cork conducted its own, institutional-level Research Quality Review. It had no overall findings that noted the that arts and humanities research was a central strength of the university, with independent peer-review panels instead expressing reservations about the entire review process (UCC 2010; for more detail see Hazelkorn et al. 2013: 123-7).

19. One source of such topical discussion is Richard Holmes's blog, http://rankingwatch.blogspot.com/.

20. http://www.scimagojr.com/countryrank.php.

21. http://www.scimagojr.com/aboutus.php.

22. This is defined as follows: 'Number of citations of all dates received by the documents published during the source year-i.e. citations in years X, X 1, X 2, X 3... to documents published during year $\mathrm{X}$. When referred to the period 1996-2014, all published documents during this period are considered.' http://www.scimagojr.com/help.php.

\section{References}

Ahmad, S. S. (2012) 'Performance Indicators for the Advancement of Malaysian Research with Focus on Social Science and Humanities', Procedia - Social and Behavioral Sciences, 68: 16-28.

Amsler, S. S., and Bolsmann, C. (2012) 'University Ranking as Social Exclusion', British Journal of Sociology of Education, 33//2: 283-301.

Arnold, E. et al. (2012) Research Centres in Ireland: Funding Models, Oversight Mechanisms and Vision of a Future Research Centre Landscape. Dublin: Forfás. Belfiore, E. (2014) 'Impact', "Value” and "Bad Economics”: Making Sense of the Problem of Value in the Arts and Humanities', Arts and Humanities in Higher Education, 14/1: 95-110.

Belfiore, E., and Upchurch A., eds. (2013) Humanities in the Twenty-First Century: Beyond Utility and Markets. Basingstoke: Palgrave Macmillan.

Benneworth, P. (2015) 'Putting Impact Into Context: The Janus Face of the Public Value of Arts and Humanities Research', Arts and Humanities in Higher Education, 14/1: 3-8. doi:10.1177/1474022214533893

Benneworth, P., and Jongbloed, B. W. (2009) 'Who Matters to Universities? A Stakeholder Perspective on Humanities, Arts and Social Sciences Valorisation', Higher Education, 59/5: 567-88.

Bookstein, F. L. et al. (2010) 'Too Much Noise in the Times Higher Education Rankings', Scientometrics, 85/1: 295-9. doi:10.1007/s11192-010-0189-5

Butler, D. (2010) 'University Rankings Smarten Up', Nature, 464: 16-7. doi:10.1038/464016a.

Capaccioni, A., and Spina, G. (2012) 'Italian SSH Journals in Journal Citation Reports (JCR) and in SCImago Journal Rank (SJR): Data and First Analysis', Italian Journal of Library and Information Science, 3/1: 1-9.

Central Statistic Offic [CSO]. (n.d.) Seasonally Adjusted Standardised Unemployment Rates (SUR), (Pubd online) < http://www.cso.ie/en/statis tics/labourmarket/principalstatistics/seasonallyadjustedstandardisedunem ploymentratessur > accessed 3 May 2016.

Central Statistics Office [CSO]. (2015) International Trade in Services 2014, (Pubd online) http://www.cso.ie/en/releasesandpublications/er/its/internatio naltradeinservices2014/ accessed 3 May 2016.

Central Statistics Office [CSO]. (2016) Trade Statistics January 2016, (Pubd online) http://www.cso.ie/en/media/csoie/releasespublications/documents/ externaltrade/2016/trade_jan2016.pdf > accessed 3 May 2016.

Chambers, A. (2014) T.K. Whitaker: Portrait of a Patriot. Dublin: Gill and Macmillan.

Clancy, P. (2015) Irish Higher Education: A Comparative Perspective, Dublin: Institute of Public Administration.

Collini, S. (2012) What are Universities For? London: Penguin Books.

Coolahan, J. (2008) 'Coming to Terms with the 1997 Act: the National University of Ireland Senate, 1997-2007', in Dunne, T., Coolahan, J., Manning, M., and Tuathaigh, G. Ó. (eds), The National University of Ireland, 1908-2008: Centenary Essays. Dublin: UCD Press.

Creveld, M. (1999) The Rise and Decline of the State. Cambridge: Cambridge University Press.

Dagg, M. (2006) 'Public Investment in R\&D in Ireland', in O'Toole, R., and Aylward, C. (eds), Perspectives on Irish Productivity. Dublin: Forfás.

Dahler-Larsen, P. (2007) 'Evaluation and Public Management', in Ferlie, E., Lynn, L. E. Jr., and Pollitt, C. (eds), The Oxford Handbook of Public Management, pp. 615-39. Oxford: Oxford University Press.

Dahler-Larsen, P. (2015) 'The Evaluation Society: Critique, Contestablility and Skepticism', Spazio Filosofico, 13: 21-36.

De Bellis, N. (2009) Bibliometrics and Citation Analysis: From the Science Citation Index to Cybermetrics. Lanham, MD: The Scarecrow Press. 
de Mesnard, L. (2012) 'On Some Flaws of University Rankings: The Example of the SCImago Report', Journal of Socio-Economics, 41/5: 495-9.

Department of Education and Skills [DES]. (2011) National Strategy for Higher Education to 2030. Report of the Strategy Group. Dublin: Department of Education and Skills.

Department of Jobs, Enterprise and Innovation [DJEI]. (2015a) Survey of Research \& Development in the Higher Education Sector 2012/2013. Dublin: Department of Jobs, Enterprise and Innovation. http://www.enter prise.gov.ie/en/Publications/Survey_of_Research_and_Development_in_ the_Higher_Education_Sector_2012_2013_PDF_567KB_.pdf accessed 3 May 2016.

Department of Jobs, Enterprise and Innovation [DJEI]. (2015b) Review of Progress in Implementing Research Prioritisation - Report of the Independent Panel. Dublin: Department of Jobs, Enterprise and Innovation. Department of Jobs, Enterprise and Innovation [DJEI]. (2015c) Innovation 2020: Excellence, Talent, Impact. Dublin: Department of Jobs, Enterprise and Innovation.

Desrosières, A. (1998) The Politics of Large Numbers: A History of Statistical Reasoning. Cambridge, MA: Harvard University Press.

Dichev, I. D. (2001) 'News or Noise? Estimating the Noise in the U.S. News University Rankings', Research in Higher Education, 42/3: 237-66.

Donovan, C. (2007) 'The Qualitative Future of Research Evaluation', Science and Public Policy, 34: 585-97. doi:10.3152/030234207x256538.

Donovan, C. (2011) 'State of the Art in Assessing Research Impact: Introduction to a Special Issue', Research Evaluation, 20/3: 175-9.

Duncan, M., and Rouse, P. (2015) Creating Ireland: Research and the Role of the Humanities and Social Sciences. Dublin: Irish Research Council.

EGFSN. (1998) First Report of the Expert Group on Future Skills Needs. Dublin: Expert Group on Future Skills Needs.

Elwood, L. P., and Leyden, V. M. (2000) 'Strategic Planning and Cultural Considerations in Tertiary Education Systems: The Irish Case', Scandinavian Journal of Educational Research, 44/3: 307-23.

Enserink, M. (2009) 'Fix Funding Agency's "Original Sin," ERC Review Panel Demands', Science, 325/5940: 523-4.

European Research Council [ERC]. (2015) ERC Funding Activities 20072013. Luxembourg: Publications Office of the European Union.

EVIDENCE. (2009) Research Strengths in Ireland: A Bibliometric Study of the Public Research Base. Dublin: Forfás.

EVIDENCE. (2010) Research Strengths in Ireland: A Bibliometric Study of the Public Research Base - Extension Report. Dublin: Forfás.

Ferrini, C. (2014) 'Research "Values" in the Humanities: Funding Policies, Evaluation and Cultural Resources. Some Introductory Remarks', Humanities, 4/1: 42-67.

Ferriter, D. (2010) The Transformation Of Ireland 1900-2000. Dublin: Profile Books.

Filsinger, D. (2016) 'Ten Years of the Center for Evaluation: Review Purview - Preview', in Stockman, R. and Meyer, W. (eds), The Future of Evaluation: Global Trends, New Challenges, Shared Perspectives, pp.2-8. Basingstoke: Palgrave Macmillan.

Forfás. (2011) Research and Development Funding and Performance in the State Sector 2009-2010. Dublin: Forfás.

Forfás. (2012) Report of the Research Prioritization Steering Group. Dublin: Forfás.

Forfás. (2004) Building Ireland's Knowledge Economy. Dublin: Forfás.

Forfás. (2006) Strategy for Science, Technology and Innovation 2006 - 2013. Dublin: Forfás.

Forfás. (2008) The Higher Education R \& D Survey 2006 (HERD). Dublin: Forfás.

Garvin, T. (2005) Preventing the Future: Why was Ireland so poor for so long? Dublin: Gill and Macmillan.

Geuna, A., and Piolatto, M. (2016) 'Research Assessment in the UK and Italy: Costly and Difficult, but Probably Worth it (at Least for a While)', Research Policy, 45/1: 260-71. doi:10.1016/j.respol.2015.09.004.
Giménez-Toledo, E., Tejada-Artigas, C., and Mañana-Rodríguez, J. (2013) 'Evaluation of Scientific Books' Publishers in Social Sciences and Humanities: Results of a Survey', Research Evaluation, 22/1: 64-77.

Gwynn, A. (1938) 'The Medieval University of St. Patrick's, Dublin', Studies: An Irish Quarterly Review, 27/106: 199-212.

Hammarfelt, B. (2014) 'Using Altmetrics for Assessing Research Impact in the Humanities', Scientometrics, 101/2: 1419-30. doi:10.1007/s11192-0141261-3.

Harkin, S., and Hazelkorn, E. (2014) 'Restructuring Irish Higher Education through Collaboration and Merger', in Curaj, A., Georghiou, L., Harper, J. C., Pricopie, R., and Egron-Polak, E. (eds), Mergers and Alliances in Higher Education: International Practice and Emerging Opportunities. Dordrecht: Springer.

Hazelkorn, E. (2011) 'Everyone Wants To Be Like Harvard- Or Do They: Cherishing All Missions Equally' (Pubd online) http://arrow.dit.ie/csercon/ 17 accessed 3 May 2016.

Hazelkorn, E. (2014) 'Making an Impact: New Directions for Arts and Humanities Research', Arts and Humanities in Higher Education, 14/1: 25-44.

Hazelkorn, E. (2015) Rankings and the Reshaping of Higher Education: The Battle for World-Class Excellence. Basingstoke: Palgrave Macmillan.

Hazelkorn, E., and Moynihan, A. (2010) 'The Research Mission of Higher Education Institutions outside the University Sector: Striving for Differentiation', in Kyvik, S., and Lepori, B. (eds), The Research Mission of Higher Education Institutions outside the University Sector, pp. 175-97. Dordrecht: Springer Netherlands.

Hazelkorn, E., and Gibson, A. (2016) 'Another Year, Another Methodology: Are Rankings Telling Us Anything New?', International Higher Education, 84: 3-4. http://ejournals.bc.edu/ojs/index.php/ihe/article/view/9105/8205 accessed 3 May 2016.

Hazelkorn, E., Gibson, A., and Harkin, S. (2015) 'From Massification to Globalisation: Reflections on the Transformation of Irish Higher Education', in Rafter, K. (ed.), The State in Transition, pp. 235-60. Dublin: New Island.

Hazelkorn, E. et al. (2013) Recognising the Value of the Arts and Humanities in a Time of Austerity (Pubd online) http://arrow.dit.ie/cserrep/42 accessed 3 May 2016.

Hicks, D. (2012) 'Performance-based University Research Funding Systems', Research Policy, 41/2: 251-61. doi:10.1016/j.respol.2011.09.007.

Huang, M., and Chang, Y. (2008) 'Characteristics of Research Output in Social Sciences and Humanities: From a Research Evaluation Perspective', Journal of the American Society for Information Science and Technology, 59/11: 1819-28.

Hug, S. E., Ochsner, M., and Daniel, H.-D. (2013) 'Criteria for Assessing Research Quality in the Humanities: A Delphi Study Among Scholars of English Literature, German Literature and Art History', Research Evaluation, 22/5: 369-83.

Hughes, A., and Kitson, M. (2012) 'Pathways to Impact and the Strategic Role of Universities: New Evidence on the Breadth and Depth of University Knowledge Exchange in the UK and the Factors Constraining Its Development', Cambridge Journal of Economics, 36/3: 723-50. doi:10.1093/cje/bes017.

ICSTI. (1999) Technology Foresight Ireland-An ICSTI Overview. Dublin: Forfás.

ICSTI. (2015) Consultation Paper for Successor to Strategy for Science, Technology and Innovation. Dublin: Interdepartmental Committee on Science, Technology and Innovation.

INDECON. (2011) Assessment of the Economic Impact of the Arts in Ireland. Dublin: INDECON.

Irish Business and Employers Confederation [IBEC]. (2008) Foresight in the Arts, Humanities and Social Science - Irish Business and Employers Confederation Submission. Dublin: IBEC.

Kirby, P. (2010) Celtic Tiger in Collapse: Explaining the Weaknesses of the Irish Model, 2nd edn. Basingstoke: Palgrave Macmillan. 
Kirby, P., and Murphy, M. (2011) Towards and Second Republic: Irish Politics after the Celtic Tiger. London: Pluto Press.

KNAW. (2005) Judging Research on its Merits: An Advisory Report by the Council for the Humanities and the Social Sciences Council. Amsterdam: Royal Netherlands Academy of Arts and Sciences.

KNAW. (2011) Quality Indicators for Research in the Humanities. Amsterdam: Royal Netherlands Academy of Arts and Sciences.

Lund, H. S. (2015) 'The Humanities as a Public Good and the Need for Developing Accountability Strategies', Humanities, 4/1: 98-108.

Luukkonen, T. (2012) 'Conservatism and Risk-Taking in Peer Review: Emerging ERC Practices', Research Evaluation, 21/1: 48-60.

Luukkonen, T. (2014) 'The European Research Council and the European Research Funding Landscape', Science and Public Policy, 41/1: 29-43.

Maassen, P., and Stensaker, B. (2011) 'The Knowledge Triangle, European Higher Education Policy Logics and Policy Implications', Higher Education, 61/6: 757-69.

Marginson, S. (2009) 'Open Source Knowledge and University Rankings', Thesis Eleven, 96/1: 9-39.

Mittelstrass, J. (2015) 'Humanities Under Pressure', Humanities, 4/1: 80-6.

Morgan, B. (2014) 'Research Impact: Income for Outcome', Nature, 511/ 7510: S72-5. doi: 10.1038/511S72a

Newfield, C. (2011) Unmaking the Public University: The Forty-Year Assault on the Middle Class. Cambridge, MA: Harvard University Press.

O’Connell, C. (2012) 'Research Discourses Surrounding Global University Rankings: Exploring the Relationship with Policy and Practice Recommendations', Higher Education, 65/6: 709-23.

Oancea, A. (2014) 'Research Assessment as Governance Technology in the United Kingdom: Findings from a Survey of RAE 2008 Impacts', Zeitschrift Für Erziehungswissenschaft, 17/S6: 83-110.

Ochsner, M., Hug, S. E., and Daniel, H. D. (2013) 'Four Types of Research in the Humanities: Setting the Stage for Research Quality Criteria in the Humanities', Research Evaluation, 22/2: 79-92.

OECD. (1996) The Knowledge-Based Economy. Paris: Organisation for Economic Cooperation and Development.

OECD. (2015) A Contribution to the New Strategy for Science, Technology \& Innovation (SSTI II). Trento: Organisation for Economic Coordination and Development.

Oireachtas Éireann. (1992) Regional Technical Colleges Act, 1992. Dublin Stationery Office.

Oireachtas Eireann. (1997) Universities Act, 1997. Dublin, Ireland: Stationery Office.

Penfield, T. et al. (2014) 'Assessment, Evaluations, and Definitions of Research Impact: A Review', Research Evaluation, 23/1: 21-32. doi:10.1093/reseval/rvt021

Pinto, M. J., and Fernandes, S. (2015) 'New Questions Arise: Are Bibliometric Indicators Adequate for Evaluating the Scientific Production of the Social Sciences and Humanities?', Qualitative and Quantitative Methods in Libraries, 161-9.

Royal Irish Academy. (2007) Advancing Humanities and Social Sciences Research in Ireland. Dublin: Royal Irish Academy.

Royal Irish Academy. (2011) The Appropriateness of Key Performance Indicators to Research in arts and Humanities Disciplines: Ireland's Contribution to the European Debate. Dublin: Royal Irish Academy.
Royal Irish Academy. (2015). Does Ireland Need a Minister for Higher Education and Research? Dublin: Royal Irish Academy.

Ruane, F., and Whelan, B. (2011) 'Building Research Capacity in the Social Sciences-Alternatives Approaches', Journal of the Statistical and Social Inquiry Society of Ireland, XL: 133-52.

Scott, J. C. (1998) Seeing Like a State. New Haven, CT: Yale University Press.

Soh, K. (2013) 'Misleading University Rankings: Cause and Cure for Discrepancies between Nominal and Attained Weights', Journal of Higher Education Policy and Management, 35/2: 206-14.

Soh, K. C. (2012) 'Simpson's Paradox and Confounding Factors in University Rankings: A Demonstration Using QS 2011-12 Data', European Journal of Higher Education, 2/4: 389-402.

Stockmann, R., and Meyer, W. (2016) 'Evaluation between Science and Utility', in Stockmann R., and Meyer W. (eds), The Future of Evaluation: Global Trends, New Challenges, Shared Perspectives, pp. 238-51. Basingstoke: Palgrave Macmillan.

Stratilatis, C. (2014) 'University Rankings and the Scientification of Social Sciences and Humanities', Ethics in Science and Environmental Politics, 13/ 2: $177-92$.

Taylor, M. Z. (2016). The Politics of Innovation. Oxford: Oxford University Press.

Telesis Consultancy Group. (1982) A Review of Industrial Policy, Dublin: NESC.

UCC. (2010) Quality Promotion Committee Research Quality Review 2009. Cork: University College Cork, https://www.ucc.ie/en/media/research/ researchatucc/documents/RQR-report.pdf accessed 3 May 2016.

Walsh, J. (2009) The Politics of Expansion: The Transformation of Educational Policy in the Republic of Ireland, 1957-72. Manchester: Manchester University Press.

Walsh, J. (2014) 'The Transformation of Higher Education in Ireland, 1945-80', in Loxley, A., Seery, A., and Walsh, J. (eds), Higher Education in Ireland: Practices, Policies and Possibilities, pp. 5-32. Basingstoke: Palgrave Macmillan.

Watermeyer, R. (2012a) 'From Engagement to Impact? Articulating the Public Value of Academic Research', Tertiary Education and Management, 18/2: 115-30.

Watermeyer, R. (2012b) 'Issues in the Articulation of "Impact": The Responses of UK Academics to "Impact" as a New Measure of Research Assessment', Studies in Higher Education, 39/2: 1-19.

Watermeyer, R. (2014) 'Impact in the REF: Issues and Obstacles', Studies in Higher Education, 41/2: 199-214.

Whelan, K. (2014) 'Ireland's Economic Crisis: The Good, the Bad and the Ugly', Journal of Macroeconomics, 39: 424-40.

Zhang, Q., Larkin, C., and Lucey, B. (2015) Innovative Cultures in Ireland's Higher Education Institutions: An Assessment. (Pubd online) http://ssrn. com/abstract $=2604196$ accessed 3 May 2016 .

Zhang, Q., Larkin, C., and Lucey, B. (2014) The Economic Impact of Higher Education Institutions in Ireland: Evidence from Disaggregated Input Output Tables, Vol. 6 (Pubd online) http://papers.ssrn.com/sol3/Papers. cfm?abstract_id=2508614 accessed 3 May 2016.

Zhang, Q., Larkin, C., and Lucey, B. M. (2016) 'Universities, Knowledge Exchange and Policy: A Comparative Study of Ireland and the UK', Science and Public Policy, 44/2 174-185. 